\title{
Entrepreneurship Empowerment of UMKM Diversity Growth in Cultural Environment Semarang
}

\author{
Sri Indrahti *, Fildza Andita Meirina \\ Department of History, Faculty of Humanities, Diponegoro University, Semarang - Indonesia
}

\begin{abstract}
This paper seeks to research and portray how business behavior of UMKM with diversity type of entrepreneurial in cultural environment in Semarang. Entrepreneurial was given of empowerment from Government by means of the training with the purpose to create independence entrepreneurship with emphasize potential entrepreneurship. Entrepreneurs open the opportunity of economic and employment to alleviate property. It's not just economy, entrepreneurship UMKM had a principles that are applied, such as hard-work, be patient, priority to quality of product, and teach how to sharing with others. That principles brings cultural behavior in entrepreneurship spirit. Data collection methods in this paper consists of primary data by interviews with entrepreneurship of UMKM, and secondary data, by books, publication journal, government policy, and digital newspaper. This research wants to portray the benefits that entrepreneurship of UMKM is not only centered on economic, but for cultural environment to be principles from entrepreneurship of UMKM.
\end{abstract}

Keywords entrepreneurship; business; UMKM; culture; cultural environment; characteristics

\section{Introduction}

Usaha Mikro, Kecil dan Menengah (UMKM) in Semarang become aim for entrepreneurship to open the opportunity and provide the employment. Based on Government Policy number 20 of 2008 about Semarang UMKM and be participate in UMKM potential in community to alleviate poverty [1]. It is also aim at increase Semarang economic potential and attract tourists by offering local products. Entrepreneurial are also equipped with training to achieve the vision and mission of UMKM Semarang. The training includes the financial management up to marketing of UMKM [2]. UMKM Empowerment is in government policy paragraph 1 clause 8 about general requirements that empowerment carried out by government is developing UMKM entrepreneurship able to independent business and be able to compete [3]. UMKM empowerment is expected able to evolve for

\footnotetext{
*Corresponding author : indrahti@gmail.com
} 
create independence and be the center of economic with any potential and characteristic of UMKM.

The kind of products offers are varied, for example Handy craft, Batik, Food (Wingko, Bread, Pia), etc. Semarang government is not only wants to increase public economy, but want to emphasize the culture as characteristic and symbol of Semarang, and also respect for local products and industries.

UMKM products efforted by Semarang government through Dewan Kerajinan Nasional (Dekranas) as a step to preserve the cultures in the middle of globalization [4]. The strategy carried out by UMKM entrepreneurial with marketing the products with portray the cultural characteristic of Semarang as economic selling value. This strategy must be accompanied with use of eco-packaging material. This strategy is purpose to minimize waste. Therefore, the purpose of empowerment in UMKM is awareness management of waste and environment preservation [5]. For the example, utilization of indigo as natural ingredient in making Batik. Indigo be the main ingredient for coloring because the nature is sustainable packaging, easy to get it, and Batik can be used of anyone, specially the consumer who has a sensitive skin.

Cultural and human is the things can't be divided. The knowledge of human creating the culture which be the symbol and characteristic of human. According to Van Peursen, culture is the manifestation of life with the activity which is build a relationship and interaction with the environment includes the tradition, rule, tradition, treasure, and inheritance [6]. Manifestation of culture consists of idea, activity, and artifacts which means be the orientation of UMKM entrepreneurship. Therefore, authors interest to research about UMKM entrepreneurship empowerment with variety of products in culture environment. Local cultural values that have local-knowledge and are the maintained by the community (Jepara carving) provide to increasing entrepreneurial desires [9].

\section{Data Collection Methods}

In this research, data collection consists of primary data by in depth interview. In depth interviews with entrepreneurs includes UMKM entrepreneurship in Semarang, which includes kind of products, start from Handy craft, culinary, services, etc.

Informant election determined by variation products which can be represent kind of UMKM in Semarang, with the expectation of representing entrepreneurial activities that exist in the types, although the represent can't be said as a whole entrepreneurship. Informant is someone be active in entrepreneurship (UMKM) and the owners or business management (in general management at once as an owner), the leader which course of business, start from production, marketing, and optimizing human resources.

Meanwhile, the secondary data was collected from written sources both books, publication journal, government policy, and digital newspaper. Some informants who have been interviewed made a profile description and then written the portray of activities related efforts to cultural entrepreneurial empowerment that carried out as a conclusion in addition to entrepreneurial values that can be learned academically as well as those that grown from local values of the local community [7]. 


\section{Result and Discussion}

From the results of collection of data research, it can be made some descriptions of UMKM actors with various products, including:

\subsection{Batik Semarang 16}

Batik Semarang 16, originally pioneered by Umi, which grow and development in Meteseh Tembalang villages. In their journey, the management entrepreneurship take over by Edy Prayitno (Umi's Husband) and have rapid development because Umi attend with their child study in Malaysia.besides the handmade batik productions with own creation motive, edy enterprise hostels and rent for the formal meeting and non-formal. Workshop and museum or rather, gallery is in the same location so that looks magnificent, for consumer or prospective buyers be able to see the process made a Batik from the beginning until done and have a look any coloring main material of Batik which is planted around the gallery. According to Edy, many plagiarism of Batik in others craftsmen, however it has no legal efforts have been made yet. Remember the rules are not clear enough and the processing are complex. Respond that, which can do is only handed over to the market, it must be able to distinguished from the first craftsmen and anothers (Interview with Edy Prayitno, April 10, 2020). He wished that the future will be orderly about copyright in Batik activities. The culturals sometimes give motivation for artist, he said activities connection with set a mind at rest, specially religious activities. He realized that many people has a different background of life and different to doing religious activities in his worker. For example, the worker listening the wiridan, listening spiritual music, and listening the loud music, and throw out anger that can be relieve his heart. All process Batik activities, he said it will be influence for the result. Between of workers of Batik one another, although the guide or direction of model is the same, but the results will be different. From the worker which work with religious activities, the results are more quitter and soft and has an own marketing. As well as the processing with anger, it will be more hard and rough and the results are popular with people who enjoying with life-hard and full of challenge. Process of Batik of handmade have a variety prices.

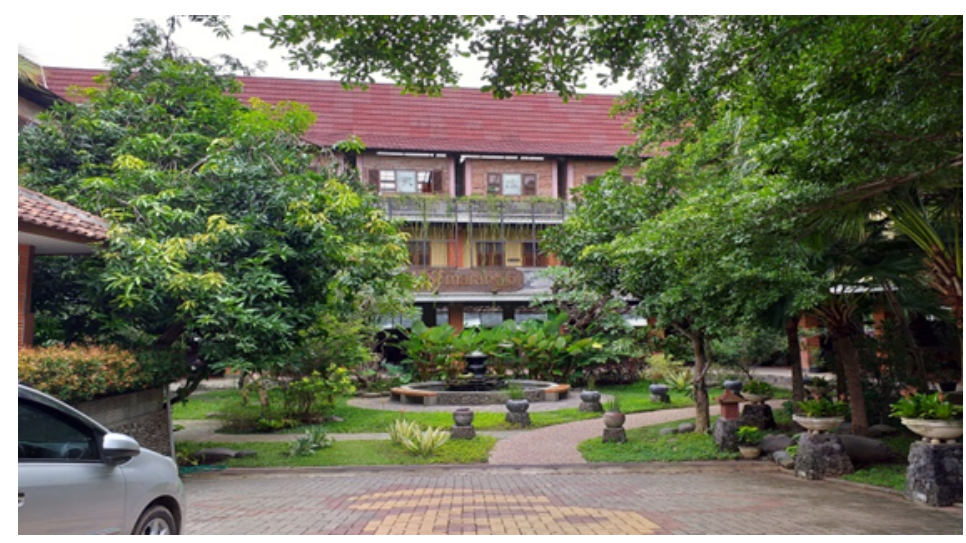

Fig 1. Batik Semarang 16 


\subsection{Wingko Babat Cap Pohon Kelapa}

Wingko babat already become identical with Semarang city, after she laid off from her company, Isma Rahayu choose to enterprise to make Wingko and learned from one of her family in East Java. Started from open the stand in her main room of house, and take advantage of social media and her house near from Diponegoro University, and then the Wingko often ordered by students as souvenirs when they're go home (Interview with Ismaya Rahayu at 7 April 2020). She said to initiate the entrepreneur is not easy but if patiently occupied, the results are quite ancouraging and made the Wingko can be process in her house and the same time caring for her children who still need attention. Many things which given spirit for her business is Isma always routine to sharing with her neighborhood if she has a lot of ordered. Isma assumed sharing is the part of shodaqoh and believe if she sharing to others it will be back again in the form of anothers and more than before. So how to cultivate the spirit of business and never give up if the conditions are not good enough for example when vacations, and also her business will be influence too because the main consumer for her products are the students.

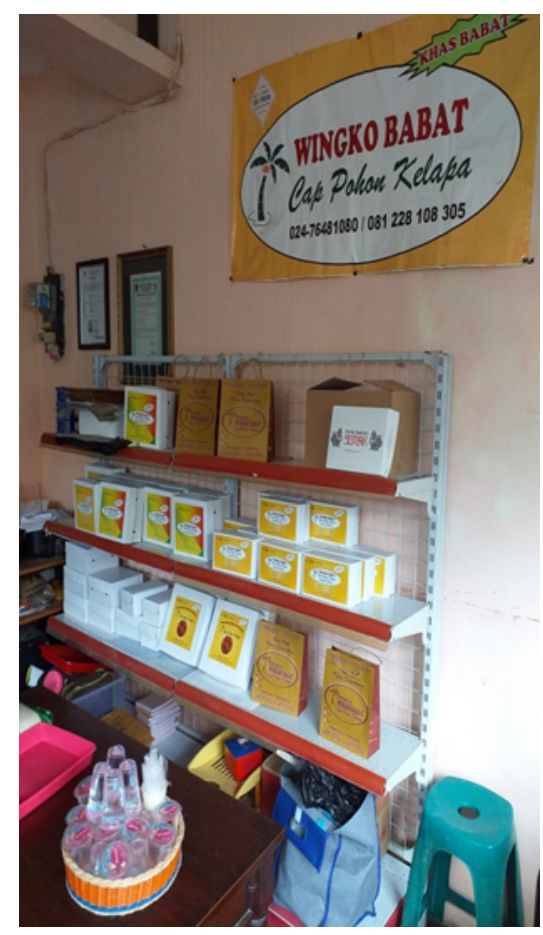

Fig 2. Wingko Babat Cap Pohon Kelapa

\subsection{Pia Aras (Head of Durma Cooperative)}

Pia Aras was initiated by Budi Mariani who has hobby to make any kind of culinary. One of the culinary she wants to pursue is Pia, in marketing journey she's finally given the brand "Aras". In entrepreneurship, she realize, it will be joys and sorrows in various kinds, and experienced that she knew when her brand is plagiarized by others entrepreneurship (Interview with Mariani, April 7, 2020). However, they're had a same products, but basically everything's has own characteristic and the market is different each other. From 
her experienced, she's guided by principles that still maintain products quality so that consumer don't feel disappointed.

To encompass consumer, what is she do is make a business network by directly involved with business activities that have links with local-government program. With the capacity as head of UMKM cooperative Dumas Srondol Semarang, for example the training, venture capital loan with low interest. What is in the training and gathering activities of the UMKM actors, Mariani said is more emphasized for the sustainability of economic activities UMKM themselves.

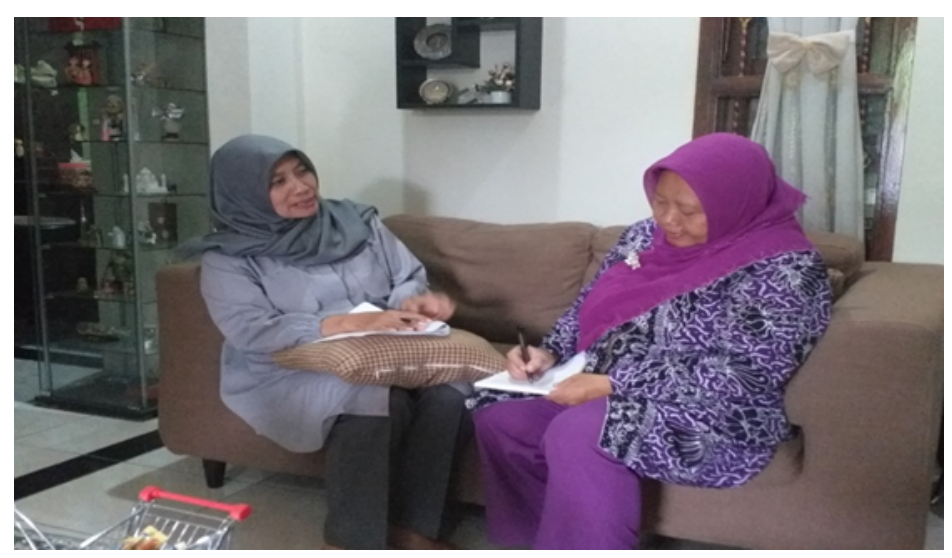

Fig 3. Pia Aras

\subsection{Catering Lucky}

Many kind of cake that he learned, it will be the capital by Lucky who has spirits to coordinate his neighbors in Kopi Mie Community. Lower-middle class costumers become the priority, but obviously, it will be his lucky, because the consumer have amount increased with the lower prices over times. Besides that, Lucky has many ordered of Catering. Success of his business is supported by his ability to communication in associations. Through the social media becomes his inspiration to look and go forward (Interview with Lucky, April 15, 2020). He always attended to religious activities in church, because in entrepreneurship is must be supported with pray and always sharing with his neighbors when there is excessive orders as a part of gratitude. 


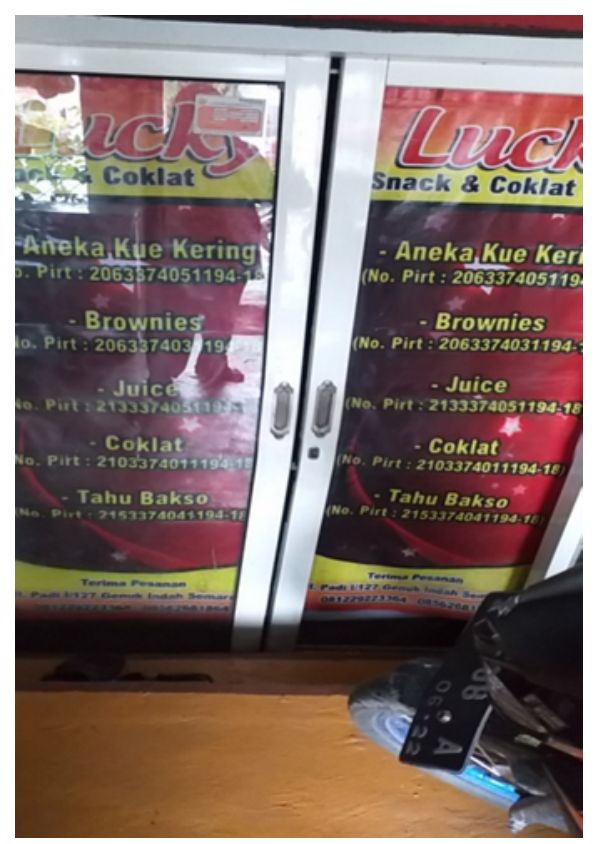

Fig 4. Catering Lucky

\subsection{Kampung Nasi Ayam}

Kampung Nasi Ayam is the seller community of nasi ayam. Although sellers with the same products, under the management of Tri Asih, between sellers don't compete with each other, even they're sharing any information for each other how that the products is liked by customer. This happened because each seller has their own costumer in different region. In general, they sell around and although if it selling on they own village, nature in groups and the profits will be given for household cash and do the village care and becomes more beautiful and cleaner. Togetherness and the same boat make nasi ayam seller living in harmony with each other even for business. This will be their successfull main capital in business. Give each other positive information for their successful entrepreneurship. Initially the traders is traveler, and precisely this same boat changed their economic condition more better, anyone has their home in overseas (Interview with Tri Asih, April 12, 2020). 


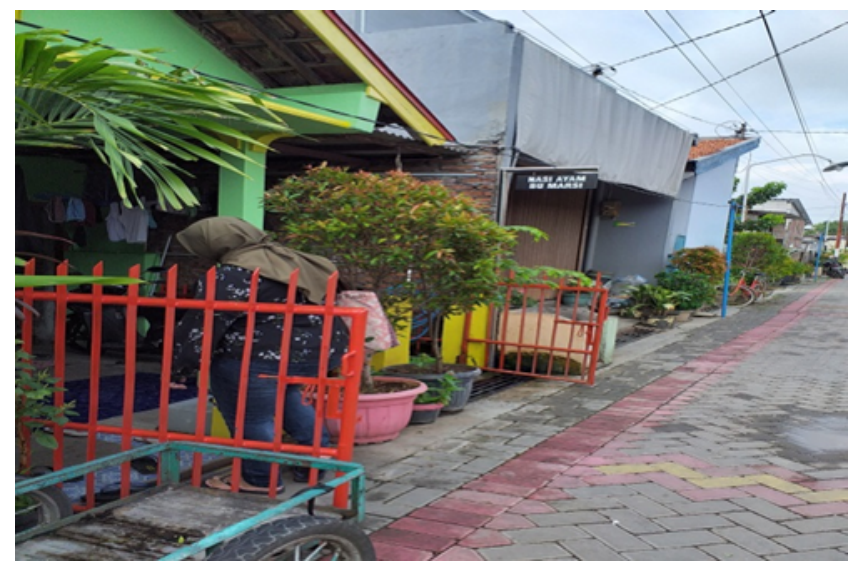

Fig 5. Kampung Nasi Ayam

\subsection{Sepatu Kulit Kurnia}

Pursue shoes repair services finally make shoes with any creativity. Kurnia Finally received shoes ordered in general from among parents which need and feel suitable with Kurnia's made. pursue in entrepreneurship more than 20 years with his wife in narrow alley but always visited by costumer. Many activities are always priority of costumer wishes, listen what their wants and also realize it with prices and the quality is more better than the seller in market (Interview with Kurnia, April 12, 2020). That principles he believed to be fundamental entrepreneur, it's alright to have low profits, but always has a work everyday and build a relation. satisfaction consumer makes him spirited to hard-work even though he's no young anymore.

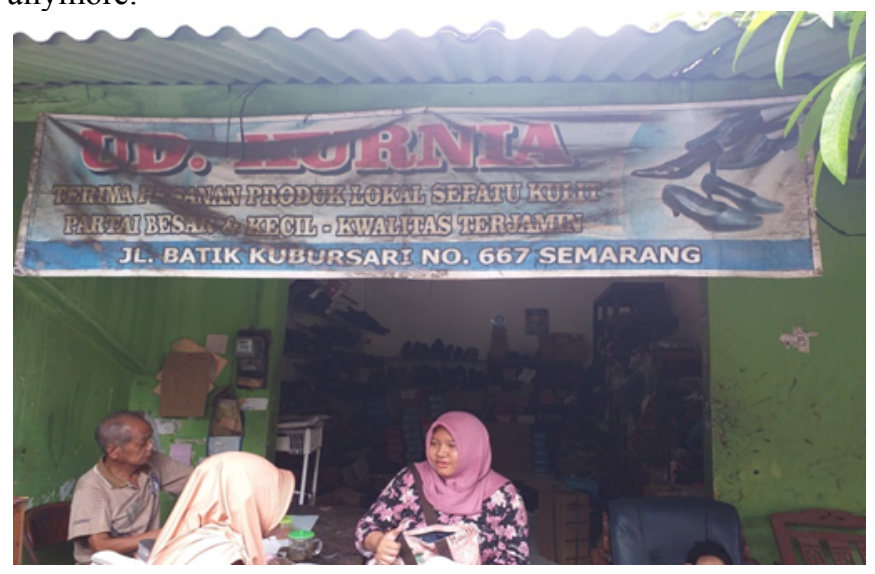

Fig 6. Sepatu Kulit. Kurnia

\section{Conclusion}

UMKM entrepreneurship in Semarang even they're have a variety of products, but they're have same cultural environment characteristic in entrepreneurship, that is diligent for business. Doing UMKM business is not easier, many obstacle and struggle to get the profits. Never give up with diligent in business purpose to business still maintained and develop. And then, be patient in hard situations is reflects tough attitude in 
entrepreneurship. The patient attitude of entrepreneur is based on prayer and worship in accordance with the beliefs that are lived to be more meaningful and not just about business with the economic. And then, priority of products quality for increase UMKM entrepreneurship reputation. Reputation may give trust and satisfaction for consumer with the products. Furthermore, UMKM actors may compete with others. Based on data collecting, cultural environment in entrepreneurship UMKM with sharing the knowledge to each other never decrease the profits, it's because consumer may choose the products with the quality. UMKM actors not only sharing the knowledge, but sharing the profits to others. They're realize that sharing never decrease what they already have, it will increase wealth more than before. These characteristics are manifested in the principle of entrepreneurship to always diligent, praying, prioritizing quality products and not forgetting to share the knowledge and profits with others. The components in the principle if followed by other entrepreneurship, it will be realized the meaning of entrepreneurship.

\section{References}

1. "Dinas Koperasi dan Usaha Mikro Kota Semarang-Jawa Tengah", (https://diskopumkm.semarangkota.go.id/diskop-umkm/visi-misi, accessed on April 20, 2020)

2. Y.R. Suci, Perkembangan UMKM (Usaha Mikro Kecil Dan Menengah) Di Indonesia, Jurnal Ilmiah Cano Ekonomos, Vol. 6, No. 1, pp 51-58 (2017)

(https://media.neliti.com/media/publications/58432-ID-none.pdf, downloaded on May 29, 2020)

3. Undang-Undang No. 20 Tahun 2008 (https://www.ojk.go.id/sustainablefinance/id/peraturan/undang-undang/Pages/Undang-Undang-Republik-IndonesiaNomor-20-Tahun-2008-Tentang-Usaha-Mikro,-Kecil,-dan-Menengah.aspx, accessed on May, 2020)

4. V. Tamaya, S. Sulandri, and D. Lituhayu, Optimalisasi Kampung Batik dalam Mengembangkan Industri Batik Semarang di Kota Semarang, Journal of Public Policy and Management, Vol. 2, No. 1, pp 1-14 (2013)

(https://ejournal3.undip.ac.id/index.php/jppmr/article/view/1612, downloaded on April 20, 2020)

5. N.K.T Martuti, I. Hidayah, and Marguani, Pemanfaatan Indigo sebagai Pewarna Alami Ramah Lingkungan bagi Pengrajin Batik Zie, Jurnal Panrita Abdi, Vol. 3, No. 2 (2019), pp 133-143 (http://journal.unhas.ac.id/index.php/panritaabdi, downloaded on May 28, 2020)

6. C.A.V Peursen, Strategi Kebudayaan (Edisi baru), diterjemahkan oleh Dick Hartoko, Yogyakarta: Penerbit Kanisius. (1976)

7. S. Indrahti, Potret Jiwa Kewirausahaan Pengusaha Kerajinan Ukir di Jepara, Humanika, (2017)

8. E. Suherman, Desain Pembelajaran Kewitrausahaan, (2008)

9. S. Indrahti, S. Tri Sulistyo, Y. Rochwulaningsih, D. Respati Puguh and Alamsyah. Penggalian Nilai-Nilai Budaya Lokal Untuk Meningkatkan Daya Saing Industri Kerajinan Ukir Dalam Era Globalisasi. Jepara: Bappeda. (2008)

10. W. Soemanto, Pendidikan Wiraswasta. Malang: Penerbit Bumi Aksara. (1984) 


\section{Informants List}

1. Name : Rini (Tlogo Kreasi Sulam Pita)

Age $\quad: 54$ years old

Address : Kota Semarang

Phone : 085741234861

2. Name : Isma Rahayu (Wingko Babat Cap Pohon Kelapa)

Age $: 38$ years old

Address : : Tembalang Pesona Asri Blok A9, 001/004, Kramas, Kota Semarang Phone : 08228108305

3. Name : Lucky (Cathering Lucky)

Age : 56 years old

Address : : Sayong, Kota Semarang

Phone : 081229223364

4. Name : Budi Mariani (Pia Aras)

Age $: 54$ years old

Address : : Taman Beringin III Blok E8, Tambakaji, Kec. Ngaliyan, Kota Semarang Phone : 081325594836

5. Name : Edy Prayitno (Batik Semarang 16)

Age $\quad: 58$ years old

Address : Jl. Raya Samberrejo, Meteseh, Kec. Tembalang, Kota Semarang

Phone

0811289444 
6. Name : Tri asih (Kampung Nasi Ayam)

Age $: 48$ years old

Address : Jl. Brotojoyo Barat IV, Panggung Kidul, Kec. Semarang Utara, Kota

Semarang

Phone : 081326463930

7. Name : Listyowati (Batik Listyowati)

Age : $: 38$ years old

Address : Jl. Bukit Seroja II/ E 177, Kota Semarang

Phone : 081327992111

8. Name : Kurnia (Sepatu KulitKurnia)

Age $: 65$ years old

Address : Jl. Batik, rejomulyo, Kec. Semarang Timur, Kota Semarang

Phone :

9. Name : Sari (Roti Kering)

Age $\quad: 48$ years old

Address : Banyumanik No. 9, Kota Semarang

Phone : 081242879569

10. Name : Ana (Sulam Pita)

Age : 45 years old

Address : Kota Semarang

Phone : 08122550442 